work in hydro-electric engineering. During 1924-46 he was employed by the Air Ministry and the Ministry of Aircraft Production, becoming director of technical development in 1941 and director-general of technical development four years later. From 1946 until the end of 1951, when he took up his present post, $\mathrm{Mr}$. Rowe was controller of research and special developments for British European Airways. He was elected a Fellow of the Royal Aeronautical Society in 1942, and has been a member of council since that year; he is also a member of council of the Helicopter Association. In 1944 he was made C.B.E. for his work in the Ministry of Aircraft Production.

\section{Chemical Engineering in Great Britain}

Is his presidential address on April 30 to the Institution of Chemical Engineers at the thirtysecond annual meeting, Mr. Stanley Robson spoke mainly on the progress of the Institution and the steps it is taking to assist industry by the provision of highly qualified chemical engineers. The full address, which has only recently been made available, insludes many interesting figures, among which may be specially mentioned the increase in production of the chemical industry by 29 per cent from 1948 to 1952 . In the same period the number of operatives scarcely changed, indicating the greatly improved efficiency per man employed. This is no doubt largely due to the increase of 20 per cent in the number of qualified scientific workers in the industry. Membership of the Institution simultaneously increased by the satisfactory figure of 30 per cent, while training facilities, in which it is keenly interested, are now available in more than twenty colleges as opposed to four in 1934. Comparative tables showing the relative numbers of chemical engineers employed by different industries in Great Britain and in the United States, and also the numbers engaged in various occupations such as plant operation, show, generally speaking, remarkable agreement, the main differences being that 20 per cent held administrative posts in Britain, as opposed to 10 per cent in the United States, and 22 per cent undertook research and development, as against 31 per cent. It follows that statements which have been made that chemical engineers in the two countries have different functions, and that consequently their training should be on different lines, have little to support them. A more important problem is the securing of adequate supplies of men to train, and the Institution, by issuing the publication "Careers in Chemical Engineering", for which there has been a widespread demand, has made a very valuable contribution to this side of the question. As Mr. Robson pointed out, in spite of this and the many other activities of the Institution for encouraging the development of chemical engineering and keeping its members in touch with recent progress, there is no room for complacency. The present trend in the chemical industry is to build much larger and more complicated units of plant; this can only be done after extensive and costly research and by making use of chemical engineers of the first grade, with scientific training of the highest order.

\section{Bulletin of Endemic Diseases}

ImPortant developments in preventive medicine in Iraq have prompted the publication, by the Institute of Endemic Diseases, Baghdad, of a new journal, the Bulletin of Endemic Diseases, the first issue of which is dated July 1954 (6s. per issue; $20 s$. for four issues). The Bulletin will be issued approx- imately every six months and its articles will be in English. Issued with the authority of the Ministry of Health and the Government of Iraq, this new journal is tastefully produced and well printed in Baghdad. Its objects are to publish original papers on the epidemiology of parasitic and insect-borne diseases, especially those relating to Iraq. This first issue contains a detailed summary, by Dr. Gordon Pringle, of the Institute of Endemic Diseases, Baghdad, of existing knowledge of malaria in Iraq before 1946 and of its control; an article, by the same author, on the identification of adult anopheline mosquitoes of Iraq and neighbouring territories ; a preliminary study, by Hannah Zakaria, of the Biology Department, Royal College of Medicine, Baghdad, of the bionomics of snails belonging to the genus Bulinus in a locality near Baghdad, the inhabitants of which are heavily infected with schistosomiasis; a preliminary report, by Younis Bashir, of the Pathological Laboratory, Royal Hospital, Mosul, on the occurrence of infantile kala-azar in northern Iraq, with an editorial comment on other cases observed in the region of Baghdad and central Iraq and on the survey of sand-flies (Phlebotominae) of infected localities that has been begun; and an account, by Haikal Riyadh and Mohammed Azzawi, of the Institute of Endemic Diseases, Baghdad, of a comparison of the efficiency of two types of sprayer used for malaria control with DD'T. Everyone interested in the progress of knowledge of tropical medicine will welcome this addition to the literature of this subject and will wish every success to its editorial board and to the workers whose results will appear in this new Bulletin. The Institute of Endemic Diseases is establishing a library, and its secretary appeals for exchanges of journals on tropical medicine and hygiene, medical zoology and parasitology, microbiology, hydrobiology and related sciences.

\section{Histochemische Methoden}

A USEFUL new publication entitled Histochemische Methoden has appeared under the editorship of Dr. Walter Lipp, of Graz, Austria. It consists of concise working directions for carrying out the selective staining of tissues for the detection and location of specific inorganic and organic substances, chemical groupings and enzymes. General histochemical procedures such as preparation of tissues will also be covered. A short bibliography is provided with each method. The three issues which so far have appeared have included among other topics the detection of potassium, arginine, carbohydrates (polysaccharides), sulphydryl and disulphide groups, and esterases. The publisher is R. Oldenbourg, of Munich, and the price is 30 DM. a year (six parts) or 6 DM. for separate parts.

\section{Forest Products Research : Report for 1953}

THE report for 1953 of the Forest Products Research Board, together with the report of the Director of Forest Products Research (pp. vi $+62+8$ plates. London: H.M. Stationery Office, 1954. 3s. net), opens with the statement that the major work of the year has continued to be the evaluation of new tropical species of likely importance, while there has been an increasing amount of testing and assessment of sample consignments of home-grown species from the plantations of the Forestry Commission. The former work is undertaken with the object of finding new timbers from the tropical forest likely to be of 